\title{
Analysis of Length of Growing Season in Some Agro-ecological Zones Using Non-parametric Trend Test
}

\author{
Olumuyiwa Idowu OJO ${ }^{1,2 *}$, Charity C. TEMENU ${ }^{2}$, Masengo Francois ILUNGA ${ }^{1}$ \\ ${ }^{1}$ University of South Africa, Department of Civil and Chemical Engineering, South Africa; olumuyiwaojo@gmail.com (*corresponding author) \\ ${ }^{2}$ Ladoke Akintola University of Technology, Department of Agricultural Engineering, Ogbomoso, Nigeria
}

\begin{abstract}
The ever increasing population and consequently increase in demand for food and the increasing exploitation of the land justifies the need for adequate studies on rainfall as an important factor affecting agricultural production. The date of the onset of rains is an important factor in planning agricultural operations such as land preparation and sowing. The study conducted agro-statistical analysis of rainfall characteristics over three different zones of Nigeria. Daily rainfall data were collected for the period between 1971 and 2005 for 6 stations and were subjected to standard analysis to determine trends and variations in the onset dates, cessation dates, length of rainy season, number of wet days, drought episodes. The results showed that the interannual variability of the onset dates is higher than that of cessation dates with a progressive shift in both onset and cessation dates. The length of rainy season varied from 77-291 days in Guinea zone, 77-243 days for Savannah and 73-155 days for the Sahel. Changes in the length of growing season ranged between - 9 and -10 for Guinea zone, -21 and 11 days for Savannah zone and -28 and 20 days for the Sahel. Similarly, the numbers of wet days have declined over Nigeria. The information presented in this study are to serve as input for proper land and water resources management for productive agricultural enterprise across the three major agro-ecological zones of Nigeria.
\end{abstract}

Keywords: analysis; cessation; growing season; length; onset; stations

\section{Introduction}

Knowledge of trends and variations of current and historical hydro-climatological variables is pertinent to the future development and sustainable management of water resources of a given region especially within the context of global warming. Water and energy cycles and the increasing demand for water due to population and economic growth (Cannarozzo et al., 2006; Oguntunde et al., 2006). One of the very important necessities of research into climate change (Houghton et al., 1996) is to analyze and detect historical changes in the climatic system. Rainfall is a principle element of the hydrological cycle, so that understanding its behavior maybe profound social and economic significance. The detection of trends and oscillations in precipitation time series yields important information for the understanding of climate. However, the rainfall changes are particularly hard to gauge, because rainfall is not uniform and varies considerably from place to place and time to time, even on small scales. Several studies have been carried out on different temporal scales and in different parts of the globe. Existing analysis of daily series, show for some areas a positive trend in daily precipitation intensity and a tendency toward higher frequencies of heavy and extreme rainfall in the last few decades (Houghton et al., 1996). Many authors analyzed the precipitation pattern in several parts of Europe. For example, Brazdil (1992) described fluctuations of precipitation in Europe using a series of annual areal precipitation sums. Some of the results suggest spatial and temporal non-uniformity in trend exists, which generalize over large areas difficult if not impossible. Significant positive trends have been observed in the USA (Karl et al., 1995; Trenberth, 1998; Kunle et al., 1999). In Nigeria, with over $70 \%$ of the populace engaged in rain-fed agriculture, rainfall is the most important climatic variable. Therefore, the need for continuous rainfall studies cannot be over-emphasized for the purpose of long-term water resources planning and management. Change in climate is a global concern today. Shifts or variations in rainfall in its extent and distributions have direct implication for food supply. For accurate decision-making, information from processed data is required and hence the need to look into all the possible ways of analyzing data generated from the environment. 


\section{Materials and Methods}

\section{The study area}

Nigeria, located in West Africa between latitudes 4$14^{\circ} \mathrm{N}$ and longitudes $2-15^{\circ} \mathrm{E}$, has a total area of about $925,796 \mathrm{~km}^{2}$. The climate highly varied across its length dominated by the influence of three main wind currents. The ecological zones of the country are broadly grouped into three (Fig. 1), which is Guinea, Savannah and Sahel. The climate varied from semi-arid, through sub humid to humid from the north to the south. Rainfall commences at the beginning of the rainy season around March/April from the coast (in the south), spreads through the middle belt, reaching its peak between July and September, to eventually get to the northern part very much later (Oguntunde et al., 2006).

\section{Data source and collection}

In order to achieve these objective, Daily rainfall from Enugu, and Ondo states were taken as representative of Guinea Zone, while Daily rainfall from Ilorin and Yola were taken as representative of the savannah zone. The data from Kastina and Sokoto were taken as the representative of the Sahel zone of Nigeria. These six cities were selected based on availability of accurate and reliable data from the Nigerian Meteorological Agency (NIMET).

\section{Data analysis performed on each of the six stations}

Onset, cessation and length of growing season

The method propose by the Agrhymet (1996) was used to calculate the onset of rainy season (date) over the city.

\section{Non-parametric trend test}

A non-parametric test recommended by the World Meteorological Organization (WMO, 1985) called MannKendall test was used to explore trends in hydroclimatological time series and test for the trends in this study. This test can be applied in cases when the data values $X$ of a time series can be assumed to obey the model (Oguntunde et al., 2006; Dinpashoh et al., 2011):

$$
\chi=\mathrm{f}(\mathrm{t})+e i
$$

Where $f(t)$ is a continuous monotonic increasing or decreasing function of time,

Residual ei are assumed to be from the same distribution with zero mean Mann-Kendall test (Salami et al., 2002), while the value of statistic $S$ is given as:

$$
S=\sum_{k=1}^{n-1} \sum_{j=k+1}^{n} \operatorname{sgn}\left(x_{j}-x_{k}\right)
$$

Where $n$ is the length of the time series $X_{j} \ldots . . . X_{n}$, and Sgn (.) is a sign function, $X_{j}$ and $X_{k}$ are values in years $j$ and $\mathrm{k}$, respectively.

The expected value of $S$ equal zero for series without trend and the variance was computed using: $\sigma^{2}(S)=\frac{1}{18}\left[n(n-1)(2 n+5)-\sum_{p=1}^{q} t_{p}\left(t_{p}-1\right)\left(2 t_{p}+5\right)\right]$

Where:

$\mathrm{q}$ is the number of tied groups,

$t_{p}$ is the number of data values in $p^{\text {th }}$ group.

The test statistic $\mathrm{Z}$ is given as:

$$
Z=\left\{\begin{array}{cll}
\frac{S-1}{\sqrt{\sigma^{2}(S)}} & \text { if } & S>0 \\
0 & \text { if } & S=0 \\
\frac{S+1}{\sqrt{\sigma^{2}(S)}} & \text { if } & S<0
\end{array}\right.
$$

The Sen's method is used in cases with linear trend, meaning that;

$f(t)$ in equation (2) is equal to:

$f(t)=\mathrm{Q} t \pm B$

Where $Q$ is the slope and $B$ is a constant.

To get the slope estimate $Q$ in equation (6) we first calculate the slopes of all data value pairs as:

$Q_{i}=\frac{\chi_{j}-\chi_{k}}{\mathrm{j}-\mathrm{k}}$

where $j>k$.

If there are $n$ values $x_{j}$ in the time series we get as many as $N=n(n-1) / 2$ slope estimates $Q_{i}$.
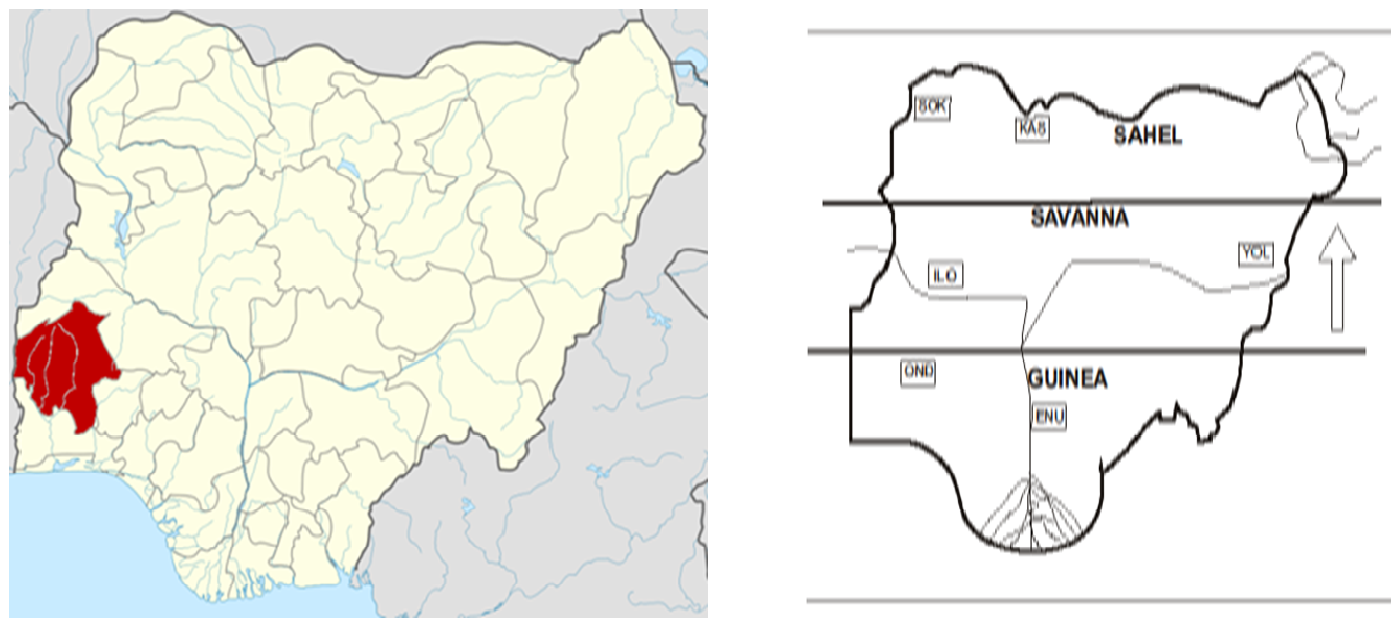

Fig. 1. The ecological zones of Nigeria 
The Sen's estimator of slope is the median of these $N$ values of $Q_{i}$, thus both trend and slope tests were calculated using MAKESENS 1.0 software.

\section{Results}

Summary description of rainfall characteristics for Guinea zone: Enugu and Ondo

The result of onset dates, cessation dates, length of growing season, and number of wet and dry days for Guinea Zone represented by Enugu and Ondo are as presented in Tables 1 and 2. The observation in Table 1 showed that rain generally starts in Enugu by February. The onset of rain at Enugu ranges from $23^{\text {rd }}$ of February (54DOY) to $1^{\text {st }}$ of May (121 DOY) with the earliest cessation date in Enugu was $12^{\text {th }}$ of October (285 DOY) while the latest cessation date was $19^{\text {th }}$ of Nov. (324 DOY). The shortest length of rainy season in Enugu was 77 days while the longest was 215 days as shown in Table 1. The length of rainy season (LGS) in Enugu ranges from 77 days to 215 days and the number of dry days (NDD) in Enugu ranges from 221 days to 290 days while the number of wet days (NWD) ranges from 75 days to 144 days.

For Ondo station, the result of onset dates, cessation dates, length of rainy season and number of wet and dry days in Ondo is as presented in Table 2. The observation showed that rain starts in Ondo by March. The onset of rain in Ondo ranges from $9^{\text {th }}$ of February $(68 \mathrm{DOY})$ to 1 st of May (121 DOY) as shown in Table 2, while the earliest cessation date in Ondo was $28^{\text {th }}$ of September (271 DOY) while the latest cessation date was $7^{\text {th }}$ of Dec (341 DOY). Furthermore, the number of dry days (NDD) in Ondo ranges from 257 days to 273 days while the number of wet days (NWD) ranges from 92 days to 108 days.

\section{Summary description of rainfall characteristics for} Savanna Zone: Ilorin and Yola

The results of onset dates, cessation dates, length of rainy season and number of wet and dry days for the savanna is as presented in Table 3. Table 3 showed onset of rain in Ilorin station ranges from $14^{\text {th }}$ of March $(73 \mathrm{DOY})$ to $29^{\text {th }}$ of April (120 DOY). The earliest cessation date in Ilorin was $30^{\text {th }}$ of September (273 DOY) while the latest cessation date was $8^{\text {th }}$ of Nov. ( 313 DOY). Table 3 showed that the shortest length of rainy season at Ilorin was 171 days while the longest was 235 days. Furthermore, the number of dry days (NDD) in Ilorin ranges from 269 days to 298 days while the number of wet days (NWD) ranges from 67 days to 97 days.

For Yola station, the results of onset dates, cessation dates, length of rainy season, and number of wet and dry

Table 1. Onset, cessation, length of growing season (LGS), number of dry days (NDD) and number of wet days (NWD) in Enugu

\begin{tabular}{|c|c|c|c|c|c|c|c|}
\hline & & & & & & & \\
\hline Year & Normal date & Julian date & Normal date & Julian date & LGS & NDD & NWD \\
\hline 1971 & 21-Mar & 80 & $17-\mathrm{Oct}$ & 290 & 147 & 256 & 109 \\
\hline 1972 & 14-Mar & 74 & $27-\mathrm{Oct}$ & 301 & 145 & 255 & 110 \\
\hline 1973 & 29-Mar & 88 & $25-\mathrm{Oct}$ & 298 & 145 & 255 & 110 \\
\hline 1974 & 2-Apr & 92 & $30-\mathrm{Oct}$ & 303 & 92 & 229 & 137 \\
\hline 1975 & 6-Apr & 96 & 17-Nov & 321 & 143 & 254 & 111 \\
\hline 1976 & 10-Mar & 70 & 6-Nov & 311 & 87 & 226 & 139 \\
\hline 1977 & 13-Apr & 103 & $17-\mathrm{Oct}$ & 290 & 131 & 248 & 117 \\
\hline 1978 & 22-Mar & 81 & 5-Nov & 309 & 132 & 249 & 117 \\
\hline 1979 & 23-Feb & 54 & 24-Nov & 328 & 81 & 223 & 142 \\
\hline 1980 & 21-Apr & 112 & 22-Nov & 227 & 108 & 237 & 129 \\
\hline 1981 & 4-Mar & 63 & $31-\mathrm{Oct}$ & 304 & 125 & 245 & 120 \\
\hline 1982 & 28-Feb & 53 & 4-Nov & 308 & 144 & 255 & 111 \\
\hline 1983 & 1-May & 121 & 12-Oct & 285 & 215 & 290 & 75 \\
\hline 1984 & 8-Apr & 99 & 12-Nov & 317 & 155 & 260 & 105 \\
\hline 1985 & 12-Mar & 71 & 7-Nov & 311 & 121 & 243 & 122 \\
\hline 1986 & 7-Mar & 66 & 4-Nov & 308 & 164 & 265 & 101 \\
\hline 1987 & 20-Mar & 79 & $16-\mathrm{Oct}$ & 289 & 165 & 265 & 100 \\
\hline 1988 & 5-Mar & 65 & $28-\mathrm{Oct}$ & 302 & 129 & 247 & 118 \\
\hline 1989 & 14-Apr & 104 & $31-\mathrm{Oct}$ & 304 & 141 & 253 & 112 \\
\hline 1990 & 8-Apr & 98 & 16-Nov & 320 & 120 & 243 & 123 \\
\hline 1991 & 14-Mar & 73 & 5-Nov & 309 & 77 & 221 & 144 \\
\hline 1992 & 14-Mar & 74 & 6-Nov & 311 & 138 & 252 & 114 \\
\hline 1993 & 5-Apr & 95 & 1-Nov & 305 & 129 & 247 & 118 \\
\hline 1994 & 2-Apr & 92 & $30-\mathrm{Oct}$ & 303 & 134 & 250 & 116 \\
\hline 1995 & 14-Apr & 104 & 6-Nov & 310 & 119 & 242 & 123 \\
\hline 1996 & 10-Mar & 70 & $26-\mathrm{Oct}$ & 300 & 135 & 250 & 115 \\
\hline 1997 & 11-Mar & 70 & 11-Nov & 332 & 115 & 240 & 125 \\
\hline 1998 & 18-Apr & 108 & $30-\mathrm{Oct}$ & 303 & 142 & 254 & 112 \\
\hline 1999 & 5-Apr & 95 & $31-\mathrm{Oct}$ & 304 & 119 & 242 & 123 \\
\hline 2000 & 24-Mar & 86 & 6-Nov & 312 & 126 & 249 & 117 \\
\hline 2001 & 29-Mar & 88 & 16-Oct & 289 & 123 & 244 & 121 \\
\hline 2002 & 6-Mar & 65 & 5-Nov & 305 & 112 & 239 & 127 \\
\hline 2003 & 11-Apr & 101 & 8-Nov & 312 & 149 & 257 & 108 \\
\hline 2004 & 6-Apr & 97 & 19-Nov & 324 & 124 & 245 & 121 \\
\hline 2005 & 14-Apr & 104 & 3-Nov & 307 & 133 & 249 & 116 \\
\hline
\end{tabular}


Table 2. Onset, cessation, length of growing season (LGS), number of dry days (NDD) and number of wet days (NWD) in Ondo

\begin{tabular}{|c|c|c|c|c|c|c|c|}
\hline & & & & & & & \\
\hline Year & Normal date & Julian date & Normal date & Julian date & LGS & NDD & NWD \\
\hline 1971 & 19-Feb & 50 & 7-Dec & 341 & 291 & 257 & 108 \\
\hline 1972 & 14-Mar & 74 & $27-\mathrm{Oct}$ & 301 & 227 & 238 & 128 \\
\hline 1973 & 14-Mar & 73 & 4-Nov & 308 & 235 & 247 & 118 \\
\hline 1974 & 20-Mar & 79 & 3-Nov & 307 & 228 & 240 & 125 \\
\hline 1975 & 17-Mar & 76 & 4-Dec & 338 & 262 & 234 & 131 \\
\hline 1976 & 26-Feb & 57 & 18-Nov & 323 & 266 & 235 & 131 \\
\hline 1977 & 25-Mar & 84 & 26-Oct & 299 & 215 & 245 & 120 \\
\hline 1978 & 19-Mar & 78 & 3-Nov & 307 & 229 & 219 & 146 \\
\hline 1979 & 14-Mar & 73 & 3-Nov & 334 & 261 & 208 & 157 \\
\hline 1980 & 20-Feb & 51 & 3-Dec & 338 & 287 & 232 & 134 \\
\hline 1981 & 9-Mar & 68 & 10-Nov & 314 & 246 & 242 & 123 \\
\hline 1982 & 24-Feb & 55 & 19-Nov & 323 & 268 & 251 & 114 \\
\hline 1984 & 1-Mar & 61 & $30-\mathrm{Oct}$ & 303 & 242 & 242 & 92 \\
\hline 1985 & 27-Feb & 58 & $31-\mathrm{Oct}$ & 304 & 246 & 273 & 92 \\
\hline 1986 & 22-Feb & 53 & 1-Nov & 305 & 252 & 255 & 110 \\
\hline 1987 & 7-Mar & 66 & $25-\mathrm{Oct}$ & 298 & 232 & 244 & 121 \\
\hline 1988 & 5-Mar & 65 & 2-Nov & 307 & 242 & 240 & 126 \\
\hline 1989 & 21-Mar & 80 & 1-Nov & 305 & 225 & 249 & 116 \\
\hline 1990 & 1-Apr & 91 & 9-Nov & 313 & 222 & 250 & 115 \\
\hline 1991 & 22-Feb & 53 & $30-\mathrm{Oct}$ & 303 & 250 & 233 & 132 \\
\hline 1992 & 17-Mar & 77 & 9-Nov & 314 & 237 & 241 & 125 \\
\hline 1993 & 14-Feb & 45 & 10-Nov & 314 & 269 & 233 & 132 \\
\hline 1994 & $18-\mathrm{Feb}$ & 49 & $17-\mathrm{Nov}$ & 321 & 272 & 261 & 104 \\
\hline 1995 & 9-Feb & 40 & 6-Nov & 310 & 270 & 237 & 128 \\
\hline 1996 & $10-\mathrm{Feb}$ & 41 & $27-\mathrm{Oct}$ & 301 & 260 & 233 & 133 \\
\hline 1997 & 1-Apr & 91 & $31-\mathrm{Oct}$ & 304 & 213 & 245 & 120 \\
\hline 1998 & 2-Apr & 92 & $23-\mathrm{Nov}$ & 327 & 235 & 253 & 112 \\
\hline 1999 & 2-Mar & 61 & 10-Nov & 314 & 253 & 242 & 123 \\
\hline 2000 & 24-Mar & 84 & 6-Nov & 311 & 227 & 249 & 117 \\
\hline 2001 & 4-Mar & 63 & 12-Nov & 316 & 253 & 246 & 119 \\
\hline 2002 & 9-Mar & 68 & 28-Sep & 271 & 203 & 261 & 104 \\
\hline 2003 & 18-Mar & 77 & 14-Nov & 318 & 241 & 244 & 121 \\
\hline 2004 & 25-Mar & 85 & 18-Nov & 323 & 238 & 247 & 119 \\
\hline 2005 & 12-Mar & 71 & 2-Nov & 306 & 235 & 249 & 116 \\
\hline
\end{tabular}

days for the savanna zone were as presented in Table 4. The onset of rain in Yola ranges from $6^{\text {th }}$ of April $(96 \mathrm{DOY})$ to $27^{\text {th }}$ of May (127 DOY) are shown in Table 4. However, the earliest cessation date in Yola was $6^{\text {th }}$ of October $(280$ DOY) while the latest cessation date was $12^{\text {th }}$ of Nov. (316 DOY). Table 4 also showed that the shortest length of rainy season at Yola was 77 days while the longest was 243 days. Furthermore, the number of dry days (NDD) in Yola ranges from 221 days to 304 days while the number of wet days (NWD) ranges from 64 days to 144 days.

Summary description of rainfall characteristics for Sabel zone: Sokoto and Kastina

The results of onset dates, cessation dates, length of rainy season, and number of wet and dry days for the savanna zone were as presented in Table 5 . The observation showed the onset of rain in Sokoto station ranges from $2^{\text {nd }}$ of May (122 DOY) to $24^{\text {th }}$ of June (175 DOY). The earliest cessation date in Sokoto was $9^{\text {th }}$ of September $(252$ DOY) while the latest cessation date was $13^{\text {th }}$ of October $(287$ DOY). Table 5 showed that the shortest length of rainy season at Sokoto was 73 days while the longest was 155 days. Furthermore, the number of dry days (NDD) in Sokoto ranges from 306 days to 336 days while the number of wet days (NWD) ranges from 30 days to 59 days.
For Kastina station, the results of onset dates, cessation dates, length of rainy season, and number of wet and dry days for the savanna zone were as presented in Table 6. The observation showed the earliest onset date in Katsina was on $21^{\text {st }}$ of April (111 DOY) while the latest was $24^{\text {th }}$ of June (176 DOY). The result further shows that the cessation of rain at Katsina was by September. The earliest cessation date in Katsina was $10^{\text {th }}$ of September (253 DOY) while the latest cessation date was $27^{\text {th }}$ of October (300 DOY). Table 6 showed that the shortest length of rainy season at Katsina was 87 days while the longest was 153 days. Furthermore, the number of dry days (NDD) in Katsina ranges from 314 days to 325 days while the number of wet days (NWD) ranges from 40 days to 51 days.

\section{Discussion}

The date of the onset of rain is an important factor in planning agricultural and operations such as land preparation and sowing. From the analysis of the rainfall date for these six stations, it can be deduced that trends in rainfall characteristics varied across the six stations and a significant change in the four northern stations studied in Nigeria. In a related study in the Volta basin of Ghana, 
245

Oguntunde et al. (2006) reported that higher spatial reduction in the number of rainy days. Thus, the results variability than the temporal annual variations. Similar to obtained from this study partly agrees with the previous the findings of this study, Ajayi (1998) analyzed rainfall data findings of Ajayi (1998), Hess et al. (1998) Oguntunde et al. for Onne and Ibadan in Nigeria and concluded that there a (2006) and Oguntunde et al. (2011).

Table 3. Onset, cessation, length of growing season (LGS), number of dry days (NDD) and number of wet days (NWD) in Ilorin

\begin{tabular}{|c|c|c|c|c|c|c|c|}
\hline & & & & & & & \\
\hline Year & Normal date & Julian date & Normal date & Julian date & LGS & 302 & NWD \\
\hline 1971 & 29-Mar & 88 & $18-\mathrm{Oct}$ & 291 & 203 & 275 & 90 \\
\hline 1972 & 7-Apr & 98 & $14-\mathrm{Oct}$ & 288 & 190 & 266 & 100 \\
\hline 1973 & 21-Apr & 111 & $31-\mathrm{OC}$ & 304 & 193 & 259 & 106 \\
\hline 1974 & 15-Apr & 105 & 29-Oct & 302 & 197 & 273 & 92 \\
\hline 1975 & 23-Mar & 82 & $27-\mathrm{Oct}$ & 300 & 218 & 266 & 99 \\
\hline 1976 & 18-Mar & 78 & 8-Nov & 313 & 235 & 269 & 97 \\
\hline 1977 & 22-Apr & 112 & 19-Oct & 292 & 180 & 290 & 75 \\
\hline 1978 & 4-Apr & 94 & $5-\mathrm{Nov}$ & 309 & 215 & 275 & 90 \\
\hline 1979 & 21-Mar & 80 & 4-Nov & 308 & 228 & 267 & 98 \\
\hline 1980 & 17-Apr & 108 & $27-\mathrm{Oct}$ & 301 & 193 & 273 & 93 \\
\hline 1981 & 18-Apr & 108 & 26-Oct & 299 & 191 & 277 & 88 \\
\hline 1982 & 8-Apr & 98 & $31-\mathrm{Oct}$ & 304 & 206 & 274 & 91 \\
\hline 1983 & 2-Apr & 92 & $12-\mathrm{Oct}$ & 285 & 193 & 296 & 69 \\
\hline 1984 & 17-Mar & 77 & $21-\mathrm{Oct}$ & 295 & 218 & 270 & 96 \\
\hline 1985 & 24-Mar & 83 & $16-\mathrm{Oct}$ & 289 & 206 & 271 & 94 \\
\hline 1986 & 16-Mar & 75 & 5-Nov & 308 & 233 & 284 & 81 \\
\hline 1987 & 14-Mar & 73 & $20-\mathrm{Oct}$ & 293 & 220 & 268 & 97 \\
\hline 1988 & 9-Apr & 100 & $11-\mathrm{Oct}$ & 285 & 185 & 295 & 71 \\
\hline 1989 & 14-Apr & 104 & $17-\mathrm{Oct}$ & 290 & 186 & 288 & 77 \\
\hline 1990 & 13-Apr & 103 & 1-Nov & 305 & 202 & 269 & 96 \\
\hline 1991 & 9-Apr & 99 & $21-\mathrm{Oct}$ & 294 & 195 & 267 & 98 \\
\hline 1992 & 4-Apr & 95 & $31-\mathrm{Oct}$ & 305 & 210 & 292 & 74 \\
\hline 1993 & 26-Apr & 116 & $26-\mathrm{Oct}$ & 299 & 183 & 266 & 99 \\
\hline 1994 & 1-Apr & 91 & 29-Oct & 302 & 211 & 271 & 94 \\
\hline 1995 & 16-Apr & 106 & 8-Nov & 312 & 206 & 269 & 96 \\
\hline 1996 & 29-Apr & 120 & $17-\mathrm{Oct}$ & 291 & 171 & 286 & 80 \\
\hline 1997 & 11-Apr & 101 & 29-Oct & 302 & 201 & 280 & 85 \\
\hline 1998 & 12-Apr & 102 & 30-Sep & 273 & 171 & 299 & 66 \\
\hline 1999 & 14-Apr & 104 & 26-Oct & 299 & 195 & 259 & 106 \\
\hline 2000 & 26-Mar & 86 & $11-\mathrm{Oct}$ & 285 & 199 & 282 & 84 \\
\hline 2001 & 24-Apr & 114 & 9-Oct & 282 & 168 & 298 & 67 \\
\hline 2002 & 14-Apr & 104 & $18-\mathrm{Oct}$ & 291 & 187 & 275 & 90 \\
\hline 2003 & 5-Apr & 95 & 30-Sep & 273 & 178 & 294 & 71 \\
\hline 2004 & 22-Apr & 113 & $31-\mathrm{Oct}$ & 305 & 192 & 282 & 84 \\
\hline 2005 & 14-Apr & 104 & $20-\mathrm{Oct}$ & 293 & 189 & 285 & 80 \\
\hline
\end{tabular}

Table 4. Onset, cessation, length of growing season (LGS), number of dry days (NDD) and number of wet days (NWD) in Yola

\begin{tabular}{|c|c|c|c|c|c|c|c|}
\hline & & & & & & & \\
\hline Year & Normal date & Julian date & Normal date & Julian date & LGS & NDD & NWD \\
\hline 1971 & 14-May & 134 & $16-\mathrm{Oct}$ & 289 & 139 & 252 & 113 \\
\hline 1972 & 26-May & 147 & $14-\mathrm{Oct}$ & 288 & 134 & 250 & 116 \\
\hline 1973 & 16-May & 136 & 9-Oct & 282 & 145 & 255 & 110 \\
\hline 1974 & 16-May & 136 & $21-\mathrm{Oct}$ & 294 & 91 & 228 & 137 \\
\hline 1975 & 21-Apr & 111 & $24-\mathrm{Oct}$ & 297 & 143 & 254 & 111 \\
\hline 1976 & 18-May & 139 & 7-Nov & 312 & 88 & 227 & 139 \\
\hline 1977 & 5-May & 125 & $20-\mathrm{Oct}$ & 293 & 131 & 248 & 117 \\
\hline 1978 & 6-Apr & 96 & $28-\mathrm{Oct}$ & 301 & 131 & 248 & 117 \\
\hline 1979 & 2-May & 122 & 12-Nov & 316 & 81 & 223 & 142 \\
\hline 1980 & 25-Apr & 116 & $29-\mathrm{Oct}$ & 303 & 108 & 237 & 129 \\
\hline 1981 & 23-Apr & 113 & $23-\mathrm{Oct}$ & 296 & 125 & 245 & 120 \\
\hline 1982 & 27-May & 137 & $12-\mathrm{Oct}$ & 285 & 143 & 254 & 111 \\
\hline 1983 & 25-May & 125 & $12-\mathrm{Oct}$ & 285 & 215 & 290 & 75 \\
\hline 1984 & 22-Apr & 113 & $25-\mathrm{Oct}$ & 295 & 156 & 261 & 105 \\
\hline 1985 & 12-May & 132 & $27-\mathrm{Oct}$ & 300 & 121 & 243 & 122 \\
\hline 1986 & 18-May & 138 & $18-\mathrm{Oct}$ & 291 & 163 & 264 & 101 \\
\hline 1987 & 27-May & 147 & $16-\mathrm{Oct}$ & 289 & 165 & 265 & 100 \\
\hline 1988 & 18-May & 139 & $28-\mathrm{Oct}$ & 302 & 130 & 248 & 118 \\
\hline
\end{tabular}




\begin{tabular}{|c|c|c|c|c|c|c|c|}
\hline 1989 & 1-May & 120 & $11-O c t$ & 285 & 141 & 253 & 112 \\
\hline 1990 & 29-Apr & 119 & $12-\mathrm{Nov}$ & 316 & 119 & 242 & 123 \\
\hline 1991 & 1-May & 121 & 29-Oct & 302 & 77 & 221 & 144 \\
\hline 1992 & 12-May & 133 & 4-Nov & 309 & 138 & 252 & 114 \\
\hline 1993 & 26-Apr & 116 & $21-\mathrm{Oct}$ & 294 & 129 & 247 & 118 \\
\hline 1994 & 27-Apr & 117 & $28-\mathrm{Oct}$ & 301 & 133 & 249 & 116 \\
\hline 1995 & 2-May & 122 & $31-\mathrm{Oct}$ & 304 & 119 & 242 & 123 \\
\hline 1996 & 9-May & 130 & 21-Oct & 295 & 136 & 251 & 115 \\
\hline 1997 & 14-Apr & 104 & $28-\mathrm{Oct}$ & 301 & 115 & 240 & 125 \\
\hline 1998 & 18-Apr & 108 & $16-\mathrm{Oct}$ & 289 & 141 & 253 & 112 \\
\hline 1999 & 6-May & 126 & 29-Oct & 302 & 119 & 242 & 123 \\
\hline 2000 & 15-May & 136 & 9-Oct & 283 & 124 & 245 & 121 \\
\hline 2001 & 9-May & 129 & $15-\mathrm{Oct}$ & 288 & 223 & 294 & 71 \\
\hline 2002 & 10-May & 130 & $23-\mathrm{Oct}$ & 296 & 223 & 294 & 71 \\
\hline 2003 & 22-May & 142 & $14-\mathrm{Oct}$ & 287 & 223 & 294 & 71 \\
\hline 2004 & 21-Apr & 112 & 6-Oct & 280 & 218 & 292 & 74 \\
\hline 2005 & 30-Apr & 120 & 19-Oct & 292 & 243 & 304 & 61 \\
\hline
\end{tabular}

Table 5. Onset, cessation, length of growing season (LGS), number of dry days (NDD) and number of wet days (NWD) in Sokoto

\begin{tabular}{|c|c|c|c|c|c|c|c|}
\hline & & & & & & & \\
\hline Year & Normal date & Julian date & Normal date & Julian date & LGS & NDD & NWD \\
\hline 1971 & 15-May & 135 & 19-Sep & 262 & 127 & 329 & 36 \\
\hline 1972 & 6-May & 127 & 25-Sep & 269 & 142 & 327 & 39 \\
\hline 1973 & 9-Jun & 160 & 9-Sep & 252 & 92 & 325 & 40 \\
\hline 1974 & 4-Jun & 185 & $1-\mathrm{Oct}$ & 274 & 89 & 313 & 52 \\
\hline 1975 & 15-May & 135 & 15-Sep & 258 & 123 & 318 & 47 \\
\hline 1976 & 26-May & 147 & $19-\mathrm{Oct}$ & 293 & 146 & 313 & 53 \\
\hline 1977 & 28-May & 148 & 28-Sep & 271 & 123 & 316 & 49 \\
\hline 1978 & 3-Jun & 154 & 23-Sep & 266 & 112 & 321 & 44 \\
\hline 1979 & 26-May & 146 & 29-Sep & 272 & 126 & 320 & 45 \\
\hline 1980 & 23-May & 144 & 26-Sep & 270 & 126 & 325 & 41 \\
\hline 1981 & 16-May & 136 & 19-Sep & 252 & 116 & 324 & 41 \\
\hline 1982 & 10-Jun & 161 & 23-Sep & 266 & 105 & 332 & 33 \\
\hline 1983 & 15-Jun & 166 & 16-Sep & 259 & 93 & 334 & 31 \\
\hline 1984 & 12-Jun & 164 & 29-Sep & 273 & 109 & 336 & 30 \\
\hline 1985 & 25-May & 145 & 27-Sep & 270 & 125 & 328 & 37 \\
\hline 1986 & 24-Jun & 175 & 22-Sep & 265 & 90 & 335 & 30 \\
\hline 1987 & 14-Jun & 165 & 8-Oct & 281 & 116 & 332 & 33 \\
\hline 1988 & 1-Jun & 153 & 23-Sep & 267 & 114 & 323 & 43 \\
\hline 1989 & 14-Jun & 165 & $2-\mathrm{Oct}$ & 275 & 110 & 313 & 52 \\
\hline 1990 & 18-May & 138 & 13-Sep & 256 & 118 & 318 & 47 \\
\hline 1991 & 13-May & 133 & $3-\mathrm{Oct}$ & 276 & 143 & 306 & 59 \\
\hline 1992 & 22-May & 143 & 15-Sep & 259 & 116 & 324 & 42 \\
\hline 1993 & 9-Jun & 160 & 28-Sep & 271 & 111 & 325 & 40 \\
\hline 1994 & 12-Jun & 163 & 19-Sep & 252 & 89 & 316 & 49 \\
\hline 1995 & 15-Jun & 196 & 26-Sep & 269 & 73 & 316 & 49 \\
\hline 1996 & 16-May & 137 & 15-Sep & 259 & 122 & 321 & 45 \\
\hline 1997 & 2-May & 122 & 17-Sep & 260 & 138 & 316 & 49 \\
\hline 1998 & 1-Jun & 152 & 20-Sep & 263 & 111 & 312 & 53 \\
\hline 1999 & 16-May & 136 & 25-Sep & 268 & 132 & 308 & 57 \\
\hline 2000 & 2-Jun & 154 & $20-\mathrm{Oct}$ & 294 & 140 & 323 & 43 \\
\hline 2001 & 26-May & 146 & 13-Sep & 256 & 110 & 322 & 43 \\
\hline 2002 & 3-May & 124 & 6-Oct & 279 & 155 & 314 & 51 \\
\hline 2003 & 29-May & 149 & 19-Sep & 252 & 103 & 319 & 46 \\
\hline 2004 & 14-May & 135 & 19-May & 263 & 128 & 320 & 46 \\
\hline 2005 & 30-May & 150 & 24-Sep & 267 & 117 & 315 & 50 \\
\hline
\end{tabular}


Table 6. Onset, cessation, length of growing season (LGS), number of dry days (NDD) and number of wet days (NWD) in Katsina

\begin{tabular}{|c|c|c|c|c|c|c|c|}
\hline & & & & & & & \\
\hline Year & Normal date & Julian date & Normal date & Julian date & LGS & NDD & NWD \\
\hline 1971 & 10-May & 130 & 22-Sep & 265 & 135 & 333 & 32 \\
\hline 1972 & 28-May & 149 & 30-Sep & 274 & 125 & 333 & 33 \\
\hline 1973 & 4-Jun & 155 & $3-\mathrm{Oct}$ & 276 & 121 & 329 & 36 \\
\hline 1974 & 5-May & 125 & $2-\mathrm{Oct}$ & 275 & 150 & 310 & 55 \\
\hline 1975 & 12-May & 132 & 15-Sep & 258 & 126 & 314 & 51 \\
\hline 1976 & 10-Jun & 162 & $23-\mathrm{Oct}$ & 297 & 135 & 313 & 53 \\
\hline 1977 & 5-Jun & 156 & 28-Sep & 271 & 115 & 318 & 47 \\
\hline 1978 & 31-May & 151 & $27-\mathrm{Oct}$ & 300 & 149 & 312 & 53 \\
\hline 1979 & 1-Jun & 152 & 30-Sep & 273 & 121 & 317 & 48 \\
\hline 1980 & 3-May & 124 & 3-Oct & 277 & 153 & 316 & 50 \\
\hline 1981 & 17-May & 137 & 27-Sep & 270 & 133 & 314 & 51 \\
\hline 1982 & 23-May & 143 & $10-\mathrm{Oct}$ & 283 & 140 & 322 & 43 \\
\hline 1983 & 14-Jun & 165 & 20-Sep & 263 & 98 & 327 & 38 \\
\hline 1984 & 26-May & 147 & $11-\mathrm{Oct}$ & 285 & 138 & 327 & 39 \\
\hline 1985 & 16-Jun & 167 & 28-Sep & 271 & 104 & 330 & 35 \\
\hline 1986 & 24-Jun & 175 & 29-Sep & 272 & 97 & 329 & 36 \\
\hline 1987 & 28-May & 148 & 25-Sep & 268 & 120 & 327 & 38 \\
\hline 1988 & 3-Jun & 155 & 22-Sep & 266 & 111 & 310 & 56 \\
\hline 1989 & 5-Jun & 156 & 5-Oct & 278 & 122 & 313 & 52 \\
\hline 1990 & 15-May & 135 & 10-Sep & 253 & 118 & 325 & 40 \\
\hline 1991 & 11-May & 133 & 3-Oct & 276 & 143 & 327 & 38 \\
\hline 1992 & 24-Jun & 176 & 19-Sep & 263 & 87 & 324 & 42 \\
\hline 1993 & 2-Jun & 153 & 23-Sep & 266 & 113 & 322 & 43 \\
\hline 1994 & 28-May & 148 & $22-\mathrm{Oct}$ & 295 & 147 & 330 & 35 \\
\hline 1995 & 8-Jun & 159 & 7-Oct & 280 & 121 & 315 & 50 \\
\hline 1996 & 22-May & 143 & 30-Sep & 274 & 131 & 320 & 46 \\
\hline 1997 & 23-May & 148 & 14-Oct & 287 & 139 & 329 & 36 \\
\hline 1998 & 28-May & 169 & 26-Sep & 269 & 100 & 308 & 57 \\
\hline 1999 & 18-Jun & 169 & 26-Sep & 269 & 100 & 322 & 44 \\
\hline 2000 & 5-Jun & 157 & 9-Oct & 283 & 126 & 342 & 23 \\
\hline 2001 & 21-Apr & 111 & 19-Sep & 262 & 151 & 315 & 50 \\
\hline 2002 & 4-Jun & 155 & $10-\mathrm{Oct}$ & 283 & 128 & 319 & 46 \\
\hline 2003 & 26-May & 146 & $13-\mathrm{Oct}$ & 286 & 140 & 310 & 56 \\
\hline 2004 & 17-May & 138 & 30-Sep & 274 & 136 & 313 & 52 \\
\hline 2005 & 27-May & 147 & 1-Oct & 274 & 127 & 318 & 47 \\
\hline
\end{tabular}

\section{Conclusions}

The importance of adequate analysis of climatological data cannot be overemphasized. It helps in making vital decision relevant to agricultural practices. The study analyzed long-term rainfall data to determine the length of growing season in three agricultural zones (Guinea, Savannah, and Shael zones) of Nigeria. The results showed that there were variations in the rainfall changes as well as the onset and cessation dates over the stations. At Ilorin, there was significant reduction in the length of growing season and the number of wet days. Peradventure the shortened length of growing season was consequent upon the reduction in the number of wet days as well as the cessation of rain. Likewise, there was significant reduction in the length of growing season and the number of wet days in Katsina. However, at Ondo and Enugu stations, a slight delay in onset of rain as well as reduction in the number of wet days were observed, which though not statistically significant, but might unanimously be responsible for the reduction in the length of growing season. For agricultural purpose, the date of the onset of rain is more important than the cessation date since the major problem facing farmers is when to start tilling and planting. Since the study deduced that length of growing season is reducing over the years, therefore early maturing crops are needed to remedy the situation. Thus the methodology adopted in this study are useful for making maps needed for decision making at the farm and regional level and with data generated as baseline information can be used for agro-climatic mapping. Thus, the methodology used in this study can be adopted for other ecological zones the in assessment and mapping for crop zonation and land use planning.

\section{Conflicts of interest}

The authors declare that there are no conflicts of interest related to this article.

\section{References}

AGRHYMET (1996). Méthodologie de suivi des zones àrisque. Bulletin de Suivi de la Campagne Agricole au Sahel 2:2. [Available from Centre Regional AGRHYMET, B.P. 11011, Niamey,Niger.] 
248

Ajayi AE (1998). Agro-statistical analysis of rainfall data for the humid and su-humid stations of Nigeria. Unpublished M. Eng. Department of Agricultural Engineering, the Federal University of Technology, Akure Ondo-State.

Alli AA (2010). Trends and cycles of rainfall and temperature for water resources development in Nigeria. Unpublished M.Sc. Thesis. The Federal University of Technology, Akure, Nigeria.

Brazdil R (1992). Fluctuation of atmospheric precipitation in Europe. GeoJournal 27(3):275-291.

Cannarozzo M, Noto LV, Viola F (2006). Spatial distribution of rainfall trends in Sicily (1921-2000). Physics and Chemistry of the Earth 31(18):1201-1211.

Dinpashoh Y, Jhajharia D, Fakheri-Fard A, Singh VP, Kahya E (2011). Trends in reference crop evapotranspiration over Iran. Journal of Hydrology 339(3-4):422-433.

Hess TM, Stephens W, Maryah VM (1995). Rainfall trends in the North East and Zone of Nigeria (1961-1990). Agricultural and Forest Meteorology 74(1-2):87-97.

Houghton JT, Meira Filho LG, Callander BA, Harris N, Kattenberg A, Maskell K (1996). Climate change. The IPCC Second Assessment Report. Cambridge University Press. New Yorkpp 72.

Karl TR, Knight RW, Plummer N (1995). Trends in high-frequency climatevariability in the twentieth century. Nature 377(6546):217-220.
Kunkel KE, Piekler JrRA, Changnon SA (1999). Temporal fluctuation in winter and climate extremes that cause economic and human health impact: a review. Bulettin of the American Meteorological Society 80(6):1077-1098.

Oguntunde PG, Abiodun BJ, Olukunle OJ, Olufayo AA (2011). Trends and variability in pan evaporation and other climatic variables at Ibadan, Nigeria, 1973-2008. Meteorological Applications 19(4):464472.

Oguntunde PG, Friesen J, Van de Giesen N, Savenije HHG (2006). Hydroclimatology of the Volta river Basin in West Africa. Trends and variability from 1901 to 2002. Physics and Chemistry of the Earth 31(8):1180-1188.

Salmi T (2002). Detecting trends of annual values of atmospheric pollutants by the Mann-Kendall test and Sen's slope estimates-the Excel template application MAKESENS. Publications on Air Quality, No. 31. Helsinki, Finland.

Trenberth KE (1998). Atmospheric moisture residence times and cycling: implications for rainfall rates with climate change. Climate Change 39(4):667-694.

WMO (1985). The global climate system: a critical review of the climate system during 1982-1984. World Climate Data Programme. 